\title{
Pengungkapan Diri Muslimah Bercadar melalui Instagram: Pendekatan Fenomenologi
}

\section{Yopi Kusmiati ${ }^{*}$, Rayhan Bayruni ${ }^{2}$}

1 UIN Syarif Hidayatullah Jakarta, Indonesia; e-mail: yopi.kusmiati@uinjkt.ac.id

2 UIN Syarif Hidayatullah Jakarta, Indonesia; e-mail: raihanbairuny@gmail.com

Received: 2020-08-03; Accepted: 2020-12-22; Published: 2020-12-31.

\begin{abstract}
Nowdays the hijrah culture is becoming a trend. Not a few Muslim women who emigrated by wearing the veil as a face covering, but then it became a challenge for them when they get discrimination, which is linked to terrorism. The phenomenon of veiled Muslim women in Indonesia continues to increase until it has become a trendy outfit as evidenced by the number of veiled Muslim women who are increasingly open on Instagram in expressing themselves. This study uses a constructivist paradigm with qualitative methods and a phenomenological approach. The subject of the study is five Muslimah Instagram users. This study found that there was expressive self-disclosure with enlarged open areas (open self) and Islamic self-disclosure with enlarged hidden self areas. There are functions of expression, self validation, social control and relationship development experienced by veiled Muslim women, and there is no function of self clarification. This study concluded that Muslims on Instagram can influence the community in removing the negative stigma of muslims and giving direction to other muslims to stay open and not shut away from society.
\end{abstract}

Keywords: Instagram; Veiled Muslimah; Self Disclosure.

Abstrak: Saat ini budaya hijrah sedang menjadi tren. Tidak sedikit muslimah yang berhijrah dengan menggunakan cadar sebagai penutup wajah. Para muslimah bercadar ini mendapat tantangan berupa diskriminasi, diantaranya dengan dikaitkan cadar dengan terorisme. Fenomena muslimah bercadar di Indonesia terus meningkat, hingga menjadi sebuah tren berpakaian. Hal ini dibuktikan dengan banyaknya muslimah bercadar di Instagram yang semakin terbuka dalam mengungkapkan diri. Penelitian ini menggunakan paradigma konstruktivis dengan metode kualitatif dan pendekatan fenomenologi dengan subjek penelitian sebanyak lima orang pengguna Instagram muslimah bercadar. Penelitian ini menemukan bahwa terdapat pengungkapan diri secara ekspresif dengan wilayah terbuka (open self) yang diperbesar dan pengungkapan diri secara Islami dengan wilayah tertutup (hidden self) yang diperbesar. Terdapat fungsi ekspresi (expression), keabsahan diri (self validation), kendali sosial (social control) dan perkembangan hubungan (relationship development) yang dialami oleh muslimah bercadar, dan tidak ditemukan fungsi penjernihan diri (self clarification). Penelitian ini berkesimpulan bahwa muslimah bercadar di Instagram dapat memengaruhi masyarakat dalam menghapus stigma negatif muslimah bercadar dan memberikan arahan pada muslimah bercadar lainnya untuk tetap terbuka dan tidak menutup diri dari masyarakat.

Kata Kunci: Instagram; Muslimah Bercadar; Pengungkapan Diri.

\section{Pendahuluan}

Fenomena muslimah bercadar di Indonesia sudah ada sejak sepuluh tahun terakhir (Qibtiyah, 2019; Ramadhini, 2017; Ratri, 2011). Cadar sudah masuk pada trend fashion masa kini, dan perkembangan muslimah bercadar semakin terlihat di masyarakat (Dewi, 2019; Rasyid \& Bukido, 2018; Sartika \& Yusuf, 2020). Hal tersebut tercatat melalui penelitian yang dilakukan oleh Alvara Research Centre tahun 2015 yang menyatakan bahwa lebih dari 2\% muslimah Indonesia mengenakan jilbab hingga menutupi wajahnya atau mengenakan cadar (Hasanuddin \& Purwandi, 2017). Semakin ke sini, perkembangan muslimah bercadar terus meningkat di berbagai kota, dari mulai Mahasiswa hingga 
public figure. Bagi seorang muslimah, pemaknaan terhadap cadar dapat dipahami dengan tujuan menutup aurat (Syekh, 2019). Terdapat berbagai alasan muslimah yang mengenakan cadar di Indonesia, salah satunya adalah memiliki pengalaman spiritual (Cahyaningrum \& Desiningrum, 2017). Kewajiban seorang muslimah untuk menutup aurat dijelaskan dalam Al-Qur'an surat Al-Ahzab ayat 59, ayat tersebut menyatakan bahwa Allah SWT memerintahkan kepada Rasullah SAW untuk memberikan perintah kepada istri-istrinya, anak-anak perempuan dan istri-istri orang mukmin untuk menjulurkan atau memanjangkan jilbabnya ke seluruh tubuh. Tujuannya adalah untuk memberikan tanda bahwa perempuan tersebut bukanlah perempuan yang buruk. Selain itu, agar dapat dibedakan dengan perempuan Jahiliah dan terhindar dari orang yang buruk (Bahreisy, 1990).

Cadar merupakan kain yang digunakan muslimah untuk menutupi bagian kepala dan muka (KBBI, 2016; Mujahidin, 2019). Cadar atau dalam Bahasa Arab disebut sebagai niqab yang artinya adalah lubang. Hal ini dimaksudkan bahwa niqab merupakan kain untuk menutupi wajah mulai dari hidung atau bawah mata hingga ke bawah (Ratri, 2011). Dalam bahasa Persia, disebut dengan Chadar yang artinya tenda. Cadar ini dikenakan oleh perempuan bangsawan pada masa dinasti Hakhamanesh (Rahman \& Syafiq, 2017). Umumnya cadar merupakan ciri khas pakaian yang digunakan oleh muslimah yang berasal dari Timur Tengah. Kemudian cadar diperkenalkan oleh bangsa Arab atau Mesir karena iklim cuaca pada negara tersebut sangat panas, sehingga untuk melindungi wajah perempuan bangsa tersebut, dibutuhkan sebuah kain untuk melindungi dari cuaca yang panas dan dataran padang pasir yang penuh debu (Rasyid \& Bukido, 2018). Di sisi lain, cadar juga difungsikan untuk melindungi muslimah tersebut dari pandangan laki-laki, melindungi dari cuaca yang buruk, melindungi dari cedera ketika berolahraga, dan menyembunyikan bagian-bagian tertentu dari tubuh kita dan pakaian memiliki fungsi kesopanan (modesty function) (Handayani, 2018).

Para perempuan berhijab seolah berlomba-lomba tampil semenarik mungkin sesuai dengan karakteristiknya sendiri-sendiri. Berhijab dapat menjadi simbol pembebasan dari standar kecantikan. Selain menunjukkan kesan saleh, kesan menarik juga bisa dilihat dari diri perempuan berhijab. Oleh karena itu berhijab kini justru tidak lepas dari atribut-atribut kecantikan (Handayani, 2018). Menurut Fathonah K. Daud (Daud, 2018), jilbab dan cadar menjelma menjadi gaya hidup dan ditempatkan di berbagai fungsi. Kadang jilbab dipolitisir menjadi konspirasi prejudis simbol-simbol agama. Makna jilbab terkadang direduksi, dikooptasi dan disalahmaknakan untuk kepentingan sesaat.

Di sisi lain, pemakaian jilbab selain dianggap sekedar mode busana, life style, juga terkadang dianggap sebagai simbol alibi stereotip, untuk menyembunyikan identitas. Misalnya, cadar mendadak menjadi busana para perempuan yang tersandung kasus hukum di pengadilan. Di sini jilbab atau cadar dijadikan pencitraan untuk menarik simpati. Maka dengan berjilbab atau bercadar seorang kriminal berharap bisa terlepas dari sanksi sosial dan menunjukkan bahwa dirinya telah insaf (Daud, 2018).

Instagram merupakan salah satu jenis dari media jaringan sosial yang populer saat ini. Instagram adalah sebuah aplikasi berbagi foto dan video berdurasi pendek yang dapat diunggah melalui jaringan sosial (Salbino, 2013). Berdasarkan hasil survei yang dilakukan WeAreSocial.net dan Hootsuite, instagram memiliki jumlah pengguna lebih dari 800 juta pengguna (Valk, 2016). Survei pada penelitian tersebut mencatat bahwa Indonesia menjadi peringkat ketiga dengan jumlah kurang lebih 50 juta pengguna aktif dengan rata-rata kaum millennials, dan berdasarkan riset yang dilakukan oleh Center for Strategic and International Studies, alasan kaum millenials aktif menggunakan Instagram adalah untuk memperlihatkan keberadaannya dan pengakuan diri kepada publik di dunia maya (CSIS, 2017). Instagram memiliki manfaatnya sendiri, tergantung pada setiap individu yang menggunakan Instagram. Menjadi selebriti Instagram atau selebgram merupakan salah satu manfaat yang menghasilkan keuntungan tersendiri (Sakinah, 2018). Selebgram dapat terkenal, salah satunya melalui konten unggahannya serta memiliki banyak pengikut atau followers. Selain itu pemanfaatan Instagram juga digunakan oleh pendakwah untuk berdakwah.

Melihat media sosial Instagram, tidak sedikit dari muslimah bercadar yang secara sengaja terbuka dengan mengungkapkan dirinya melalui media sosial. Hal ini dilihat dari unggahan foto maupun video dalam akun pribadi beberapa muslimah bercadar. Unggahan tersebut dapat memengaruhi 
masyarakat dalam menghapus stigma negatif muslimah bercadar dan memberikan arahan pada muslimah bercadar lainnya untuk tetap terbuka dan tidak menutup diri dari masyarakat.

Reaksi baik maupun buruk tentang muslimah bercadar juga terjadi di media sosial instagram, terutama dilihat pada akun instagram yang terlalu terbuka dalam mengeskpos dirinya. Tidak dapat dipungkiri, media sosial merupakan sebuah ruang untuk berekspresi bagi para penggunanya. Roberts (1998) berpendapat bahwa internet dalam hal ini media sosial Instagram dapat membantu menghilangkan depresi dari masalah-masalah individual (Severin \& Tankard, 2001). Konsep dalam mengekspresikan suatu hal di media sosial memiliki banyak makna. Muslimah bercadar di Instagram memiliki banyak makna melalui foto atau video yang diunggahnya. Terdapat banyak jenis unggahan dalam pengguna Instagram muslimah bercadar, seperti kegiatan sehari-hari, kegiatan travelling, kegiatan berbisnis, dakwah hingga memperlihatkan ekspresi wajah berupa selfie. Konten-konten yang dimiliki muslimah bercadar tersebut memiliki pengartian tersendiri, sehingga pengungkapan diri muslimah bercadar memiliki beragam makna.

Penelitian terkait pengungkapan diri pada muslimah bercadar melalui media sosial seperti Instagram belum banyak dilakukan. Ada beberapa penelitian sebelum ini terkait pengungkapan diri, pertama, penelitian Marhadika (2019) menemukan bahwa frekuensi, valensi, kejujuran, tujuan dan maksud serta keintiman menunjukkan bahwa pengungkapan diri bergantung pada mood (suasana hati) dan tuntutan dari pihak lain, isi pesan yang disampaikan juga sesuai kebutuhan. Kedua, penelitian Fitrillah (2020) menemukan bahwa perempuan bercadar akan terbuka (open self) ketika bertemu dengan perempuan bercadar lainnya dan masyarakat menerima keberadaan mereka. Ketiga, penelitian Wahyuni (2018) menemukan bahwa penerapan komunikasi pengungkapan diri (self disclosure) seperti terjadinya proses pembukaan diri, kemauan membangun kepercayaan dengan rekan komunikasi, adanya aktivitas komunikasi verbal dan non Verbal, keberanian menyatakan perasaan, serta perilaku saling menerima dan mendukung. Keempat, penelitian Amalia (2018) menunjukkan bahwa melalui keterbukaan diri, muslimah bercadar lebih mudah untuk menyesuaikan diri terhadap orang lain. Memulai membuka diri terlebih dahulu akan lebih mempermudah dalam menyesuaikan diri dengan lingkungannya dan melalui penetrasi sosial menggerakkan sebuah komunikasi menjadi lebih dalam dan berproses dalam berhubungan dengan orang lain. Dan kelima, penelitian Sari (2014) menemukan bahwa perempuan menggunakan cadar memiliki alasan yang berbeda-beda diantaranya perintah suami dan hukum wajib berdasar dan dalam melakukan penyesuaian diri memiliki strategi tersendiri diantaranya menghindar dari lingkungan dan melakukan interakasi yang wajar dengan lingkungannya.

Berdasarkan temuan-temuan penelitian sebelumnya, dapat dijelaskan bahwa yang menjadi fokus dan perbedaan adalah pengungkapan diri beserta penerapan fungsinya pada muslimah bercadar di Instagram. Untuk menganalisa permasalahan tersebut, penelitian ini menggunakan teori pengungkapan diri Sidney Marshall Jourard dan teori Johari Window.

Pengungkapan diri atau self-disclosure merupakan komunikasi yang dikemukakan oleh Sidney Marshall Jourard (1968). Pengungkapan diri atau self-disclosure adalah sesuatu yang membuat individu transparan terhadap orang lain melalui komunikasi. Hakikat dari pengungkapan diri yang dikemukakan oleh Devito adalah bahwa informasi mengenai diri sendiri yang biasanya dirahasiakan menjadi informasi yang diberikan kepada orang lain. Informasi tersebut dapat berupa pengetahuan baru yang diterima oleh pendengar. Pengungkapan diri juga dapat berupa penjelasan tentang pikiran, perasaan dan perilaku seseorang atau orang lain yang dekat dengan pikirannya. Pengungkapan diri atau self-disclosure hakikatnya dilakukan oleh dua orang, karena semakin melibatkan komunikasi yang sedikit semakin intim informasi yang diberikan (Devito, 2011).

Hubungan yang terjalin dengan baik dapat terlihat dari adanya keseimbangan pengungkapan diri yang dilakukan antar individu. Pengungkapan diri dapat bersifat informasi berupa gagasan pribadi, perasaan serta adanya feedback yang diberikan satu dengan lainnya (Budyatna, 2011). Pengungkapan diri dapat melihat bentuk dan fungsi komunikasi yang dilakukan melalui kesadaran diri seorang individu. Hal tersebut dapat terlihat dari empat kuadran dalam teori Johari Window. Johari Window merupakan penyempurnaan dari teori yang dikemukakan oleh Joseph Luft dan Harry Ingham (1984) 
untuk melihat luas dan hubungan antara pengungkapan diri dan feedback dalam sebuah hubungan (Pearson, 2012). Kuadran tersebut memiliki fungsi untuk menjelaskan individu dalam pengungkapan diri dan memahami dirinya sendiri. Gambar 1 merupakan penjelasan kuadran pada teori Johari Window (Budyatna, 2011).

\begin{tabular}{l|c|c|}
\multicolumn{1}{c}{} & \multicolumn{1}{c}{ Saya tahu } & \multicolumn{1}{c}{ Saya tidak tahu } \\
\cline { 2 - 3 } Orang lain tahu & $\begin{array}{c}\text { Kuadran I } \\
\text { Open Self }\end{array}$ & $\begin{array}{c}\text { Kuadran II } \\
\text { Blind Self }\end{array}$ \\
\cline { 2 - 3 } $\begin{array}{l}\text { Orang lain } \\
\text { tidak tahu }\end{array}$ & $\begin{array}{c}\text { Kuadran III } \\
\text { Hidden Self }\end{array}$ & $\begin{array}{c}\text { Kuadran IV } \\
\text { Unknown Self }\end{array}$ \\
\hline
\end{tabular}

Gambar 1 Model Teori Johari Window

Pertama, Kuadran I (open self). Pada kuadran ini, informasi berupa perilaku, sikap, perasaan, keinginan, motivasi, gagasan dan hal lain diketahui oleh diri sendiri dan orang lain. Umumnya informasi ini dapat berupa nama, warna kulit, keyakinan agama dan lainnya. Daerah ini menjadi lebih luas apabila keterbukaan dilakukan dengan orang yang memberikan rasa aman dan dukungan positif. Menurut Joseph Luft (1970), semakin kecil kuadran pertama semakin buruk komunikasi yang dilakukan (Devito, 2011), artinya hubungan dalam berkomunikasi tergantung pada keterbukaan yang dilakukan seorang individu dengan individu lain. Jika individu tidak membuka dirinya, maka komunikasi akan sulit dilakukan.

Kedua, Kuadran II (blind self). Informasi dalam kuadran ini lebih diketahui oleh orang lain dibandingkan dengan dirinya sendiri. Informasi ini dapat berupa kebiasaan kecil yang dilakukan oleh diri sendiri dan tidak disadari. Kebiasaan tersebut diinformasikan oleh orang lain, sehingga dapat diketahui oleh dirinya. Hal ini juga dapat terlihat dari pengalaman terpendam yang dimiliki seseorang. Sebagian orang menyadari bahwa area ini tampaknya terlihat sangat kecil karena dirinya tidak menyadari apa yang dilakukannya, namun orang lain dapat mengetahui apa yang tidak disadari oleh dirinya. Hal tersebut dapat memberikan masalah karena dirinya tidak mengenal sikap maupun perilaku yang ia timbulkan kepada orang lain.

Ketiga, Kuadran III (hidden self). Kuadran ini menjelaskan seseorang mengetahui informasi tentang dirinya sendiri dan orang lain, namun informasi tersebut hanya disimpan oleh dirinya sendiri. Terdapat daerah ekstrim yang dimiliki pada kuadran ini. Sikap terlalu terbuka (over-disclosure) dan sikap terlalu tertutup (under-disclosure). Seseorang dengan sikap yang terlalu terbuka (over-disclosure) akan memberikan informasi tentang kisah keluarga, masalah seksual yang bersifat intim kepada orang lain dengan tidak merahasiakan apapun. Informasi yang diungkapkan tidak dibedakan dan dirahasiakan. Seseorang dengan sikap yang terlalu tertutup (under-disclosure) tidak akan memberikan informasi apapun kepada orang lain dan akan membahas selain tentang dirinya. Pada kuadran ini kerahasiaan sangat penting terjaga dalam pengungkapan diri yang dilakukan seseorang. Keempat,

Kuadran IV (unkown self). Seseorang tidak mengetahui informasi mengenai dirinya dan tidak juga diketahui oleh orang lain. Informasi ini merupakan hal-hal yang terjadi di alam bawah sadar atau hal yang tidak sering diperhatikan baik diri sendiri maupun orang lain. Kuadran ini dapat terlihat melalui interaksi yang terbuka, jujur dan rasa saling percaya terhadap orang terdekat (Devito, 2011).

Selain 4 kuadran yang sudah dijelaskan tersebut, ada beberapa fungsi yang terdapat pada pengungkapan diri atau self-disclosure, sebagaimana yang diungkapkan oleh Derlega dan Grzelak (dalam: Rotenberg, 1995) yaitu 1) expression, 2) self clarification, 3) social control, dan 4) self validation.. Expression adalah kesempatan seseorang manusia mendapat mengekspresikan perasaannya kepada orang lain. Self clarification adalah kesempatan seseorang untuk memperoleh penjelasan dan pemahaman dari orang lain mengenai masalah yang dihadapinya. Self validation adalah kesempatan untuk mendapatkan feedback dari orang lain mengenai pandangan kita, bias berupa dukungan atau sebaliknya. Social control adalah kegiatan seseorang untuk mengemukakan atau menyembunyikan 
informasi agar dapat menimbulkan kesan baik atau buruk. Relationship development adalah fungsi berbagi perasaan dan informasi untuk meningkatkan derajat keakraban.

Penelitian ini menggunakan paradigma konstruktivis dengan metode kualitatif melalui data deskriptif. Pendekatan yang digunakan adalah fenomenologi untuk melihat pengalaman yang dialami oleh muslimah bercadar dalam mengunggah konten foto atau video di Instagram. Adapun subyek penelitian yang digunakan sebanyak lima orang pengguna Instagram muslimah bercadar seperti dalam tabel 1.

Tabel 1 Nama Informan

\begin{tabular}{lcl}
\hline Nama Informan & Inisial & Nama Pengguna \\
\hline Siti Utami & SU & @sayyidati_utami \\
\hline Siti Rahmania & SR & @sayyidati_rahmania \\
\hline Difa Shidqi Al Ulya & DSU & @faqiyadee \\
\hline Ridha Maulida & RM & @maulidya47 \\
\hline Karmilah & KM & @mila.edc \\
\hline
\end{tabular}

Pengguna tersebut memiliki latar belakang yang berbeda dalam mengunggah konten berupa foto maupun video di Instagram. Pengumpulan data dilakukan dengan wawancara mendalam, observasi, dan dokumentasi. Analisis data kualitatif ini menggunakan pendekatan fenomenologi dengan empat tahapan, yaitu 1) statement, mendeskripsikan hasil fenomena yang dialami subjek penelitian; 2) meaning, hasil data yang sudah ditranskrip tersebut dipilih pernyataan-pernyataan yang penting dan relevan dengan masalah penelitian; 3) meaning themes, mengkategorisasikan pernyataan-pernyataan tersebut ke dalam sebuah tema atau unit makna; dan 4) general description of the experiences, menjelaskan dan mendeskripsikan secara menyeluruh tentang makna dan esensi dari pengalaman subjek penelitian.

\section{Pengungkapan Diri Pengguna Instagram Muslimah Bercadar dalam Memahami Dirinya}

Pada hasil temuan data yang didapatkan, pengungkapan diri kelima informan muslimah bercadar melalui Instagram terbagi menjadi dua, yaitu pengungkapan diri secara ekspresif dan pengungkapan diri secara Islami. Pengungkapan diri secara ekspresif dilakukan oleh informan SR dan RM dan pengungkapan diri secara Islami dilakukan oleh informan SU, DSU dan KM. Penjelasan mengenai pengungkapan diri pengguna Instagram muslimah bercadar dalam memahami dirinya secara ekspresif dan pengungkapan diri secara Islami dijelaskan dalam tabel 2.

Tabel 2 Pengungkapan diri Pengguna Instagram Muslimah Bercadar

\begin{tabular}{|c|c|c|c|}
\hline \multirow{2}{*}{ No. } & \multirow{2}{*}{ Nama Informan } & \multicolumn{2}{|c|}{ Pengungkapan Diri } \\
\hline & & Secara Ekspresif & Secara Islami \\
\hline 1 & SU & & $\sqrt{ }$ \\
\hline 2 & SR & $\sqrt{ }$ & \\
\hline 3 & DSU & & $\sqrt{ }$ \\
\hline 4 & $\mathrm{RM}$ & $\sqrt{ }$ & \\
\hline 5 & KM & & $\sqrt{ }$ \\
\hline
\end{tabular}

Konsep pengungkapan diri secara ekspresif dinyatakan bahwa melalui temuan data yang didapatkan bahwa kedua informan muslimah bercadar dapat mengungkapkan diri berupa informasi dan perasaannya secara tepat, atau dapat dikatakan kedua informan ini mampu secara tepat memberikan maksud, gagasan, gambaran serta perasaan yang tepat kepada followers-nya melalui ungga hannya di Instagram. Hal tersebut dimaksudkan bahwa informan muslimah bercadar secara tidak langsung menganggap Instagram merupakan media sosial yang dapat menuangkan informasi atau perasaan yang dialami oleh seseorang, sehingga apapun yang menurutnya wajar dapat diunggah 
melalui Instagram. Adanya keterbukaan yang dimiliki oleh seseorang dalam mengunggah sesuatu di Instagram. Hal tersebut dibuktikan dengan adanya dua informan muslimah bercadar yang secara terbuka mengungkapkan dirinya dengan mengunggah posting-an berupa kegiatan sehari-hari yang dilakukan hingga pada unggahan berupa foto pribadinya. Pemaknaan secara ekspresif dipahami bahwa followers yang dimiliki merupakan teman yang diketahui dan dikenal oleh informan muslimah bercadar. Karena hal tersebut, informan muslimah bercadar hanya sedikit membatasi posting-annya di Instagram.

Pengungkapan diri yang dipahami secara Islami cenderung menyatakan pikiran dan perasaannya melalui media sosial Instagram dengan hal-hal yang berkaitan dengan keislam. Hal tersebut dimaksudkan bahwa posting-an yang diunggah melalui Instagram dinyatakan secara tidak langsung atau tidak apa adanya. Ungkapan tidak langsung dilakukan karena pada dasarnya individu tersebut bersifat tertutup, namun tetap melakukan pengungkapan diri. Hal ini dibuktikan dengan adanya tiga informan muslimah bercadar yang memahami dirinya secara Islami, karena data yang ditemukan melalui Instagram terdapat beberapa posting-an yang bersifat ungkapan tidak langsung yang diutarakan. Ungkapan tersebut dijelaskan melalui pesan-pesan islam atau dakwah. Posting-an lainnya juga terdapat momen-momen yang dianggap berkesan baginya dan ingin menyatakan perasaannya dengan mengunggah foto momen tersebut dan dijelaskan kembali pada caption berupa tulisan.

Pengungkapan diri sercara ekspresif dilakukan oleh dua informan yaitu informan SR dan RM. Hal ini dimaksudkan bahwa kedua informan tersebut menganggap bahwa unggahannya bersifat ekspresif seperti adanya kesamaan pada unggahan berupa foto pribadinya. Pengungkapan diri secara Islami dilakukan oleh informan SU, DSU dan KM. Hal ini dimaksudkan dengan adanya pengungkapan diri yang dijelaskan secara tidaklangsung, seperti terdapat juga unggahan berupa tulisan pada caption feeds Instagram.

Pengungkapan diri secara ekspresif dilakukan informan SR pada unggahan dalam feeds Instagramnya. Unggahan tersebut merupakan fotodirinya yang sedang melakukan kegiatan sehariharinya, seperti kegiatannya bermain skateboard dan sedang mengikuti kajian. Terdapat juga unggahan lainnya yang secara sengaja dirinya mengunggah foto pribadinya. Hal tersebut juga dilakukan oleh informan RM dalam pengungkapan diri secara ekspresif. Unggahan tersebut terdapat pada feeds Instagram miliknya. Pengungkapan diri berupa informasi dan perasaan terlihat pada foto dirinya yang ia unggah terutama pada foto yang menunjukkan dirinya sendiri. Informan RM melakukan pengungkapan diri melalui kegiatan sehari- hari yang dilakukan olehnya. Kegiatan tersebut diunggahnya dalam feeds Instagram yang disertai caption untuk menunjukkan perasaannya dalam melakukan kegiatan tersebut.

Berbeda dengan kedua informan sebelumnya, pengungkapan diri secara Islami dilakukan oleh tiga informan lainnya. Informan pertama SU melakukan pengungkapan diri berupa informasi dan perasaan melalui unggahannya. Pengungkapan diri tersebut ia lakukan melalui fitur feeds Instagram dan highlight Instagram, pada unggahannya tidak ada yang secara langsung menampakkan dirinya. Hanya terdapat unggahan berupa tulisan maupun gambar yang menyertakan perasaannya secara tidak langsung, seperti pada unggahan kegiatan dirinya bersama kucing dan unggahan berupa gambar beserta tulisan Islami pada caption. Informan kedua DSU juga melakukan pengungkapan diri yang sama dengan informan sebelumnya. Pengungkapan diri secara Islami dilakukan dengan mengunggah momen berharga bersama rekannya melalui kegiatan yang dilakukan. Momen berharga tersebut terdapat pada sebuah foto yang diunggahnya pada feeds Instagram dengan cerita singkat tentang perasaan yang dialaminya dalam caption. Informan ketiga KM melalui unggahannya juga melakukan pengungkapan diri secara Islami. Hal tersebut terlihat pada data yang ditemukan dalam feeds Instagram dan highlight Instagram miliknya. Terdapat unggahan berupa gambar serta caption yang secara tidak langsung mengungkapkan perasaannya.

Pengungkapan diri yang dipahami secara ekspresif dapat terlihat melalui unggahan pada Instagram muslimah bercadar. Unggahan tersebut dapat terlihat pada feeds Instagram, Instagram story dan highlight Instagram. Terdapat unggahan berupa foto pribadi seperti, foto selfie maupun foto bersama teman-temannya, yang keduanya menunjukkan foto dirinya sendiri menggunakan cadar. Di 
sisi lain, terdapat juga foto berupa momen pribadinya bersama temannya, seperti kegiatan sedang berkumpul bersama teman-temannya. Unggahan tersebut diartikan sebagai unggahan yang berbentuk perasaan dan menganggap bahwa follower yang dimilikinya merupakan teman yang dikenalnya.

Berbeda halnya dengan informan muslimah bercadar yang melakukan pengungkapan diri secara Islami. Terdapat perbedaan dalam bentuk unggahan yang dilakukan. Terdapat unggahan pada feeds Instagram berupa foto pemandangan atau gambar yang sesuai dengan apa yang dirasakan dan disertai caption dengan tulisan cerita singkat yang dirasakan dan terdapat pesan Islami yang disampaikan, sedangkan tidak ada unggahan berupa kegitan pada feeds Instagram, Instagram story maupun highlight Instagram informan muslimah bercadar yang menampakkan dirinya, kegiatan tersebut seperti memberi makan kucing, maupun kegiatan berupa kajian. Unggahan pada feeds Instagram, Instagram story dan highlight Instagram berbentuk pengungkapan diri yang dilakukan secara tidak langsung. Hal tersebut dilakukan karena adanya batasan yang dimiliki oleh informan muslimah bercadar terhadap followers-nya.

Kedua pengungkapan diri tersebut sesuai dengan teori Johari Window yang digunakan pada penelitian ini. Teori Johari Window dilakukan untuk mengetahui dirinya sendiri dalam hubungannya dengan orang lain. Pada penelitian ini hubungan yang dilakukan dapat terlihat melalui kelima informan pengguna Instagram muslimah bercadar dengan followers-nya. Setiap kuadran memiliki fungsinya masing-masing. Pembahasan mengenai teori Johari Window dengan informan pengguna Instagram muslimah bercadar dijelaskan dalam beberapa kuadran.

Kuadran I (open self), menunjukkan keterbukaan individu kepada orang lain. Keterbukaan tersebut disebabkan karena keduanya mengetahui satu dengan lainnya baik dalam hal informasi, perilaku, sikap, perasaan dan lain. Pada kuadran ini, merupakan tingkatan paling baik dalam komunikasi antarpribadi. Data yang ditemukan dalam melihat pengungkapan diri informan disebabkan karena alasan yang berbeda. Hal tersebut karena perbedaan latar belakang serta pengalaman yang dialaminya saat menggunakan cadar hingga pada unggahannya di Instagram. Bentuk unggahan pada kuadran ini berupa foto yang menampakkan dirinya sendiri. Hal tersebut dilakukan karena informan ingin memberitahu kepada follower-nya apa yang sedang dirasakan olehnya secara langsung.

Kuadran II (blind self), merupakan informasi atau perasaan yang dipahami oleh orang lain, namun tidak dipahami oleh dirinya sendiri. Hal ini dapat dilakukan secara tidak sadar dalam media sosial khususnya Instagram. Informan tidak mengetahui dirinya sendiri, namun followers informan tersebut memahami apa yang tidak dipahami dirinya. Informan mengunggah kegiatan sehari-harinya, seperti kegiatan berkumpul bersama rekannya dan mengunggah posting-an berupa foto bahagia dengan caption yang sama, yang secara tidak sadar followers dapat mengetahui bahwa informan tersebut memiliki sifat yang baik dan terbuka dengan rekannya. Unggahan lainnya yang menunjukkan kuadran ini, seperti tidak adanya unggahan berupa foto pribadi yang diunggah informan muslimah bercadar, yang secara tidak langsung, followers memahami bahwa informan tersebut memiliki sifat yang tertutup.

Kuadaran III (hidden self), individu menutupi informasi mengenai dirinya dari orang lain, sehingga orang lain tidak tahu tentang informasi tersebut. Informan cenderung menutup informasi terkait dirinya sehingga followers tersebut tidak dapat memahaminya. Pengungkapan diri berupa informasi sangat terlihat disini, karena informan sangat selektif dalam mengungkapkan dirinya kepada followersnya di Instagram. Informan sangat membatasi unggahannya di Instagram. Hal ini terlihat pada tidak semua jenis unggahan yang diungkapkan oleh informan, hanya beberapa hal saja, seperti informan hanya mengunggah gambar yang disertai tulisan pada Instagramnya, tanpa memperlihatkan wajahnya. Gambar pemandangan yang disertai caption berupa tulisan merupakan ungkapan yang secara tidak langsung dipahami followers informan muslimah bercadar.

Kuadran IV (unknown self), hal yang tidak diketahui individu dan juga individu lain. Kuadran ini mengungkapkan berbagai hal yang tidak dipahami atau diketahui keduanya. Penelitian ini tidak melihat adanya data yang mendukung pada kuadran ini dalam pengungkapan diri informan muslimah bercadar melalui Instagram. 
Analisis data pada penelitian ini, pengungkapan diri secara ekspresif yang dilakukan informan SR dan RM dalam memahami dirinya, melalui unggahannya di Instagram yang digambarkan menggunakan teori Johari Window pada tabel 3.

Tabel 3 Model Pengungkapan Diri Muslimah Bercadar Secara Ekspresif

\begin{tabular}{|c|c|}
\hline $\begin{array}{c}\text { Kuadran I } \\
\text { Open Self }\end{array}$ & $\begin{array}{c}\text { Kuadran II } \\
\text { Blind Self }\end{array}$ \\
\hline Kuadran III & Kuadran IV \\
Hidden Self & Unknown Self \\
\hline
\end{tabular}

Tabel 3 merupakan model kuadran I (open self) yang diperbesar. Melalui unggahannya kedua informan SR dan RM secara terbuka mengungkapkan dirinya diInstagram. Unggahan dalam bentuk foto dirinya memberikan dampak pada kuadran I yang lebih besar dan penyempitan ruangan pada kuadran lainnya. Pada model kuadran ini keduanya disebut dengan open person atau ideal window, karena semakin besar pengungkapan diri yang dilakukan kedua informan tersebut, semakin besar keduanya mengetahui dirinya sendiri. Di sisi lain, keduanya juga membiarkan followers Instagramnya untuk mengetahui dirinya secara mendalam.

Berbeda dengan kedua informan sebelumnya, informan muslimah bercadar SU, DSU dan KM yang melakukan pengungkapan diri secara Islami memiliki kuadran yang berbeda. Berdasarkan teori Johari Window yang digunakan dapat dilihat pada tabel 4.

Tabel 4 Model Pengungkapan Diri Muslimah Bercadar Secara Islami

\begin{tabular}{|c|c|}
\hline $\begin{array}{c}\text { Kuadran I } \\
\text { Open Self }\end{array}$ & $\begin{array}{c}\text { Kuadran II } \\
\text { Blind Self }\end{array}$ \\
\hline Kuadran III & Kuadran IV \\
Hidden Self & Unknown Self \\
\hline
\end{tabular}

Terlihat pada tabel 4, terdapat kuadran III (hidden self) yang diperbesar sehingga kuadran lainnya menjadi lebih sempit. Hal ini dinyatakan bahwa individu dengan model ini merupakan individu yang suka melakukan hal yang bersifat sendiri atau menyendiri, seperti penyu. Analisis data pada unggahan informan SU, DSU dan KM merupakan unggahan yang bersifat tertutup, sehingga followers Instagram tidak mengetahui lebih dalam mengenai diri ketiga informan tesebut, seperti unggahan pada gambar pemandangan yang disertai tulisan berupa perasaanyang diungkapkan secara tidak langsung. Adanya batasan yang dilakukan oleh ketiga informan tersebut dalam mengunggah sesuatu di Instagram.

Berdasarkan hasil analisis data menggunakan teori Johari Window, pengungkapan diri yang dilakukan informan pengguna Instagram muslimah bercadar dalam memahami dirinya, memiliki dua model pengungkapan diri. Model pertama merupakan pengungkapan diri berupa open self secara ekspresif yang dilakukan oleh informan SR dan RM. Model kedua pengungkapan diri berupa hidden self secara Islami yang dilakukan oleh informan SU, DSU dan KM.

\section{Fungsi Pengungkapan Diri Pada Pengguna Instagram Muslimah Bercadar}

Berdasarkan data yang didapatkan melalui lima fungsi pengungkapan diri yang dilakukan muslimah bercadar, terdapat tiga fungsi pengungkapan diri yang dialami kelima informan muslimah bercadar yaitu fungsi expression, social control dan relationship development. Fungsi self clarification merupakan fungsi yang tidak dialami kelima informan muslimah bercadar. Fungsi self validation dialami oleh dua informan muslimah bercadar. Untuk lebih jelasnya dapat dilihat pada tabel 5. 
Tabel 5 Fungsi Pengungkapan diri Pengguna Instagram Muslimah Bercadar

\begin{tabular}{|c|c|c|c|c|c|c|}
\hline \multirow[b]{2}{*}{ No } & \multirow[b]{2}{*}{ Nama Informan } & \multicolumn{4}{|c|}{ Fungsi Pengungkapan Diri } & \multirow[b]{2}{*}{$\begin{array}{l}\text { Relationsh } \\
\text { ip } \\
\text { Developm } \\
\text { ent }\end{array}$} \\
\hline & & Expression & $\begin{array}{c}\text { Self } \\
\text { Validation }\end{array}$ & $\begin{array}{c}\text { Self } \\
\text { Validati } \\
\text { on }\end{array}$ & $\begin{array}{l}\text { Social } \\
\text { Control }\end{array}$ & \\
\hline & SU & $\sqrt{ }$ & $x$ & $x$ & $\sqrt{ }$ & $\sqrt{ }$ \\
\hline & SR & $\sqrt{ }$ & $x$ & $\sqrt{ }$ & $\sqrt{ }$ & $\sqrt{ }$ \\
\hline & DSU & $\sqrt{ }$ & $\mathrm{x}$ & $x$ & $\sqrt{ }$ & $\sqrt{ }$ \\
\hline & $\mathrm{RM}$ & $\sqrt{ }$ & $\mathrm{x}$ & $\sqrt{ }$ & $\sqrt{ }$ & $\sqrt{ }$ \\
\hline & KM & $\sqrt{ }$ & $x$ & $x$ & $\sqrt{ }$ & $\sqrt{ }$ \\
\hline
\end{tabular}

Analisis data yang didapatkan berkaitan dengan fungsi pengungkapan diri yang dijelaskan sebagai berikut:

\section{Expression}

Data yang didapatkan melalui unggahan kelima informan pengguna Instagram muslimah bercadar terdapat fungsi expression. Unggahan yang menunjukkan ekspresi pada Instagram kelima muslimah bercadar memiliki beberapa bentuk. Informan SU mengunggah tulisan dan gambar pada foto dalam feeds Instagramnya, ia juga mengunggah kegiatannya dengan hewan kucing kesukaannya dalam Instagram story. Informan DSU dan KM membagikan foto kegiatannya dengan caption berupa cerita singkat yang mewakili perasaannya. Informan SR dan RM mengunggah foto pribadinya dengan caption singkat yang diunggah dalam feeds Instagram.

Fungsi expression pada pengungkapan diri dapat memperlihatkan perasaan individu dalam hubungan antarpribadi. Bentuk expression tersebut dapat berupa gerakan non-verbal. Analisis pada penelitian ini menggunakan fungsi expression dalam pengungkapan diri informan muslimah bercadar melalui Instagram. Bentuk unggahan berupa fungsi expression dapat dibagi menjadi dua jenis. Pertama unggahan berupa foto pribadi, seperti foto selfie dan foto dirinya bersama temannya. Kedua unggahan berupa caption yang bertuliskan tentang perasaannya.

\section{Self Validation}

Data yang ditemukan pada penelitian ini menunjukkan bahwa fungsi self validation dialami oleh dua informan muslimah bercadar yaitu SR dan RM. Informan SR mendapati tanggapan berupa komentar positif melalui unggahannya di feeds Instagram. Begitu juga dengan informan RM yang mendapatkan tanggapan positif dari followers-nya. Terdapat beberapa komentar berupa emotion yang menunjukkan tanggapan positif. Dukungan pada tanggapan tersebut memberikan kebenaran pada informan muslimah bercadar.

Analisis pada penelitian ini menggunakan fungsi pengungkapan diri berupa self validation, yang merupakan individu mendapatkan pembenaran dirinya sendiri atas pengungkapan diri yang dilakukannya. Pembenaran tersebut diberikan oleh individu lainnya dalam hubungan antarpribadi. Pada penelitian ini fungsi self validation yang dialami kedua informan muslimah bercadar atas pengungkapan diri melalui unggahan Instagram. Dukungan pada fitur kolom komentar yang diberikan follower tersebut pembenaran atas diri informan muslimah bercadar.

\section{Social Control}

Penelitian yang dilakukan terhadap kelima informan muslimah bercadar terdapat adanya pengendalian sosial melalui Instagramnya. Kelima informan tersebut sangat menjaga dan membatasi unggahannya di Instagram. Melihat pada unggahan kelima muslimah bercadar tersebut memiliki perbedaan, namun tetap membatasi unggahan di Instagramnya. Kesamaan yang terlihat pada 
unggahan kelima informan tersebut pada unggahan kegiatan yang dijalaninya. Terdapat perbedaan dalam mengunggah bentuk kegiatan tersebut baik pada feeds Instagram dan Instagram story. Informan SU dan DSU mengunggah foto maupun video berupa kegiatannya tanpa menunjukkan dirinya, sementara itu berbeda dengan informan SR, RM dan KM yang secara jelas menampakkan dirinya dalam kegiatannya. Hal tersebut terjadi karena bentuk pembatasan pada unggahan di Instagram kelima informan tersebut memiliki pengalaman yang berbeda-beda. Perbedaan dalam pengalamannya terdapat pada penggunaan Instagram dan juga dirinya sebagai muslimah bercadar.

Pada penelitian ini menggunakan fungsi pengungkapan diri berupa social control sebagai alat analisis. Fungsi social control merupakan pembatasan yang dilakukan individu dalam mengatur lingkungannya. Adanya informasi yang disembunyikan untuk menjaga privasi individu tersebut. Analisis yang dilakukan pada penelitian ini kelima informan muslimah bercadar sangat menjaga dan memperhatikan unggahannya di Instagram. Hal tersebut dilakukan karena ingin menjaga citra dirinya sebagai muslimah bercadar. Pengungkapan diri yang dilakukan kelima informan muslimah bercadar melakukan fungsi social control pada unggahannya di Instagram. Informan SU hanya mengunggah sesuatu yang menurutnya penting saja dan semua unggahannya merupakan hal yang menjadi prinsipnya sebagai muslimah bercadar. Informan SR saat ini sangat mengurangi unggahan-unggahan di Instagram. Informan DSU menjaga dirinya dengan mengontrol unggahannya. Informan RM tetap bersifat terbuka dengan mengunggah foto maupun video pada Instagram miliknya, namun ia juga tetap membatasi unggahannya. Informan KM juga membatasi unggahannya di Instagram. Kelima informan tersebut menyadari bahwa dirinya adalahmuslimah bercadar dan membatasi unggahannya menurut pengalamannya masing-masing.

\section{Relationship Development}

Relationship development yang dilakukan dan setelah fungsi merupakan fungsi dari pengungkapan diri ini merupakan adanya hubungan yang dimiliki individu dengan individu lainnya. Pada fungsi relationship development terlihat adanya interaksi yang dilakukan oleh pengguna Instagram dengan followers-nya. Interaksi tersebut dapat dilakukan ketika pengguna Instagram telah mengunggah sesuatu pada feeds Instagram maupun pada Instagram story. Penelitian yang dilakukan kelima informan muslimah bercadar mengalami adanya relationship development dengan followers-nya melalui unggahannya di Instagram. Informan SU dan KM mengunggah 'question and answer' Instagram story yang secara tidak langsung memberikan interaksi dirinya denganfollowers-nya. Informan SR, DSU dan RM mengunggah foto atau gambar pemandangan pada feeds Instagram yang memberikan interaksi dengan followers-nya melalui kolom komentar.

Melihat pada unggahan tersebut terdapat dua bentuk unggahan dalam menjalin hubungan berupa interaksi yang dilakukan dengan followers Instagram. Mengunggah foto maupun video pada feeds Instagram dengan caption dapat memberikan tanggapan yang dilakukan oleh followers. Tanggapan tersebut kemudian ditanggapi kembali oleh informan hingga pada interaksi dalam bentuk percakapan. Bentuk unggahan informan selanjutnya, menggunakan fitur 'question and answer' Instagram story yang memberikan peluang bagi followers Instagram dan informan dapat menjalin hubungan, dengan adanya interaksi berupa pertanyaan yang dijawab oleh informan. Jawaban tersebut diunggah kembali pada Instagram story informan dan juga menyebutkan atau mention pengguna followers Instagram tersebut. Kedua bentuk unggahan tersebut merupakan fungsi relationship development yang dilakukan informan muslimah bercadar di Instagram.

\section{Kesimpulan}

Berdasarkan hasil penelitian, dapat disimpulkan bahwa terdapat dua model pengungkapan diri melalui Instagram yang dilakukan kelima informan muslimah bercadar. Pertama model pengungkapan diri secara ekspresif dengan kuadran open self lebih besar yang dilakukan oleh dua informan muslimah bercadar. Kedua model pengungkapan diri secara Islami dengan kuadran hidden self lebih besar yang dilakukan oleh tiga informan muslimah bercadar. Melalui hasil analisis penelitian hanya terdapat empat dari lima fungsi pengungkapan diri yang dilakukan muslimah bercadar melalui 
Instagramnya diantaranya fungsi expression, self validation, social control dan relationship development. Tidak ditemukan hasil analisis yang menjelaskan informan muslimah bercadar melalukan fungsi self clarification. Dengan model dan fungsi pengungkapan disi seperti ini, maka Penelitian ini berkesimpulan bahwa muslimah bercadar di Instagram dapat memengaruhi masyarakat dalam menghapus stigma negatif muslimah bercadar dan memberikan arahan pada muslimah bercadar lainnya untuk tetap terbuka dan tidak menutup diri dari masyarakat.

\section{Referensi}

Amalia, R. (2018). Penyesuaian Diri Muslimah Bercadar (Studi Fenomenologi Muslimah Bercadar di Majelis Taklim Al-Hikmah). Universitas Lampung.

Bahreisy, S. (1990). Terjemahan Singkat Tafsir Ibnu Katsir Jilid VI. Surabaya: PT Bina Ilmu.

Budyatna, M. (2011). Teori Komunikasi Antarpribadi: Sebuah Pengantar edisi kedua,. Jakarta: Prenada Media Group.

Cahyaningrum, D., \& Desiningrum, D. (2017). Jiwa-Jiwa Tenang Bertabir Iman: Studi Fenomena Pada Mahasiswi Bercadar di Universitas Negeri Umum Kota Yogyakarta. Empati: Jurnal Karya Ilmiah S1 Undip, 7(3), 278296.

CSIS. (2017). Ada Apa dengan Milenial? Orientasi Sosial, Ekonomi dan Politik. In Survei Nasional CSIS 2017. Jakarta.

Daud, F. K. (2018). Tren Jilbab Syar'i dan Polemik Cadar: Mencermati Geliat Keislaman Kontemporer di Indonesia. Annual Conference for Muslim Scholars, 39-53. Surabaya: UIN Sunan Ampel Surabaya.

Devito, J. A. (2011). Komunikasi Antarmanusia. Tangerang Selatan: Kharisma Publising Group.

Dewi, P. A. R. (2019). Niqab Sebagai Fashion: Dialektik Konservatisme dan Budaya Populer. Scriptura, 9(1), 9-15.

Fitrillah, C., Halik, A., \& Musi, S. (2020). Self Disclosure Muslimah Bercadar di Desa Lumaring Kabupaten Luwu. Washiyah: Jurnal Kajian Dakwah Dan Komunikasi, 1(1), 119-135.

Handayani, R. (2018). Representasi Kecantikan Perempuan Berhijab Melalui Instagram. Al-MUNZIR, 9(2), 251267.

Hasanuddin, A., \& Purwandi, L. (2017). Indonesia Middle Class Muslim: Religiosity and Consumerism. Jakarta: Alvara Research Center.

KBBI. (2016). Kamus Besar Bahasa Indonesia (KBBI). Jakarta: kementerian Pendidikan dan Kebudayaan.

Mahardika, R. D., \& Farida, F. (2019). Pengungkapan diri pada Instagram instastory. Jurnal Studi Komunikasi, $3(1), 101-117$.

Mujahidin, M. (2019). Cadar: Antara Ajaran Agama dan Budaya. JUSPI (Jurnal Sejarah Peradaban Islam), 3(1), 1116.

Pearson, J. C. (2012). Human Communication. New York: McGraw Company.

Qibtiyah, A. (2019). Hijab in Indonesia - the history and controversies. Retrieved October 20, 2020, from The Conversation website: https://theconversation.com/hijab-in-indonesia-the-history-and-controversies-102911

Rahman, A. F., \& Syafiq, M. (2017). Motivasi, Stigma dan Coping Stigma pada Perempuan Bercadar. Jurnal Psikologi Teori Dan Terapan, 7(2), 103-115.

Ramadhini, E. (2017). Jilbab Sebagai Representasi Simbolik Mahasiswi Muslim Di Universitas Indonesia. MASYARAKAT: Jurnal Sosiologi, 22(1), 81-103.

Rasyid, L. A., \& Bukido, R. (2018). Problematika Hukum Cadar dalam Islam: Sebuah Tinjauan Normatif-Historis. Jurnal Ilmiah Al-Syir'ah, 16(1), 74-92.

Ratri, L. (2011). Cadar, Media, dan Identitas Perempuan Muslim. Forum, 39(2), 29-37.

Rotenberg, K. . (Ed.). (1995). Disclosure Process in Children and Adolescents. Cambridge: Cambridge University Press.

Sakinah. (2018). Selebgram: Meraih Popularitas Melalui Dunia Maya. Etnosia: Jurnal Etnografi Indonesia, 3(1), $48-$ 71.

Salbino, S. (2013). Buku Pintar Gadget Android Untuk Pemula. Jakarta: Kunci Komunikasi.

Sari, F. H., Lilik, S., \& Agustin, R. W. (2014). Studi Fenomenologi Mengenai Penyesuaian Diri pada Wanita Bercadar. Wacana Psikologi, 6(1), 103-122.

Sartika, V., \& Yusuf, M. (2020). “ Bercadar Itu Pengakuan”; Reproduksi Makna Cadar di Kalangan Pengguna. Indonesian Journal of Religion and Society, 2(2), 87-96.

Severin, W. J., \& Tankard, J. W. (2001). Uses of the Mass Media. In Communication Theories: Origins, Methods, and Uses in the Mass Media. London: Longman.

Syekh, A. K. (2019). Pemakaian Cadar dalam Perspektif Mufassirin dan Fuqaha'. Jurnal Ilmiah Al-Mu'ashirah, $16(1), 45-60$. 
Valk, A. (2016). 50\% of Internet Users Now on Instagram. Retrieved October 20, 2020, from WeAreSocial.com website: https://wearesocial.com/blog/2016/07/50-of-internet-users-now-on-instagram

Wahyuni, S. (2018). Penerapan Komunikasi Pengungkapan Diri (Self Disclosure) Muslimah Bercadar di Fakultas Dakwah dan Komunikasi. Universitas Islam Negeri Alauddin Makassar.

(C) 2020 by the authors. Submitted for possible open access publication under the terms and conditions of the Creative Commons Attribution (CC BY SA) license (https://creativecommons.org/licenses/by-sa/3.0/). 